\title{
Synthesis of Peripherally Tetrasubstituted Phthalocyanines and Their Applications in Schottky Barrier Diodes
}

\author{
Semih Gorduk, ${ }^{1}$ Ozge Koyun, ${ }^{1}$ Oguzhan Avciata, ${ }^{2}$ Ahmet Altindal, ${ }^{3}$ and Ulvi Avciata ${ }^{1,4}$ \\ ${ }^{1}$ Faculty of Arts and Science, Department of Chemistry, Yildiz Technical University, Esenler, 34210 Istanbul, Turkey \\ ${ }^{2}$ Faculty of Chemical and Metallurgical Engineering, Department of Metallurgical and Materials Engineering, Yildiz Technical \\ University, Esenler, 34210 Istanbul, Turkey \\ ${ }^{3}$ Faculty of Arts and Science, Department of Physics, Yildiz Technical University, Esenler, 34210 Istanbul, Turkey \\ ${ }^{4}$ Department of Occupational Health and Safety, Esenyurt University, Esenyurt, 34510 Istanbul, Turkey
}

Correspondence should be addressed to Semih Gorduk; semih_grdk@hotmail.com and Ulvi Avciata; uavciata@gmail.com

Received 28 September 2017; Accepted 1 November 2017; Published 6 December 2017

Academic Editor: Maria F. Carvalho

Copyright (c) 2017 Semih Gorduk et al. This is an open access article distributed under the Creative Commons Attribution License, which permits unrestricted use, distribution, and reproduction in any medium, provided the original work is properly cited.

New metal-free and metallophthalocyanine compounds $(\mathrm{Zn}, \mathrm{Co}, \mathrm{Ni}$, and $\mathrm{Cu}$ ) were synthesized using 2-hydroxymethyl-1,4benzodioxan and 4-nitrophthalonitrile compounds. All newly synthesized compounds were characterized by elemental analysis, FT-IR, UV-Vis, ${ }^{1} \mathrm{H}-\mathrm{NMR}$, MALDI-TOF MS, and GC-MS techniques. The applications of synthesized compounds in Schottky barrier diodes were investigated. $\mathrm{Ag} / \mathrm{Pc} / \mathrm{p}-\mathrm{Si}$ structures were fabricated and charge transport mechanism in these devices was investigated using $\mathrm{dc}$ technique. It was observed from the analysis of the experimental results that the charge transport can be described by Ohmic conduction at low values of the reverse bias. On the other hand, the voltage dependence of the measured current for high values of the applied reverse bias indicated that space charge limited conduction is the dominant mechanism responsible for dc conduction. From the observed voltage dependence of the current density under forward bias conditions, it has been concluded that the charge transport is dominated by Poole-Frenkel emission.

\section{Introduction}

Phthalocyanines (Pcs) have drawn special interest due to their particular unique physicochemical properties and exhibit a variety of superb properties, such as architectural flexibility, diverse coordination properties, increased stability, improved spectroscopic characteristics, and both semi- and photoconductive characteristics $[1,2]$. These properties make them of considerable interest in diverse technological and scientific areas such as gas sensors [3], optoelectronic devices [4], static induction transistors [5], Langmuir-Blodgett films [6], electrophotographic applications [7], optical data storage [8], solar cells [9], organic field-effect transistors (OFETs) [10], and nonlinear optics [11]. In the fields of electronics and optoelectronics, Pcs are very promising candidates for future technology. The application of Pc compounds for electronics and optoelectronics devices is related to the dielectric relaxation process and electrical conductivity in the
Pc compounds and these are frequently the deciding factors about the compatibility of the material for a specific device application $[12,13]$.

As main building blocks of various electronic and optoelectronic devices such as microwave diodes, solar cells, and photodetectors [14, 15], Schottky barrier diodes (SBDs) play a crucial role in the further development of the electronic devices. High barrier height and low leakage current are the most important performance parameters for a SBD. Although important advances have been made toward high performance SBD, a lot of improvement is still needed for practical applications. There are currently a vast number of experimental studies on the realization and the manipulation of the Schottky barrier height and the leakage current using an organic interlayer. In this respect, Pc compounds offer several advantages over inorganic counterparts such as strontium titanate $\left(\mathrm{SrTiO}_{3}\right)$ [16] and hafnium dioxide $\left(\mathrm{HfO}_{2}\right)$ [17] because of their low cost, suitability for synthetic 
modification, and ease of device fabrication. Therefore, the understanding of the physical behavior of these compounds under dc condition is essential in order to decide suitability and improving the quality and performance of SBD based electronic devices.

Herein, our study presents the synthesis and characterization of new peripherally tetrasubstituted phthalocyanines. After their widespread use as active layer in many different applications, 2(3),9(10),16(17),23(24)-tetrakis-\{(2,3dihydrobenzo[b][1,4]dioxin-2-yl)methoxy $\}$ phthalocyanines are proposed as an interlayer in SBDs. The effects of the central metal ion in the Pc layer on the leakage current in $\mathrm{p}-\mathrm{Si}$ based SBDs have also been investigated.

\section{Experimental Section}

2.1. Materials and Equipment. $N, N^{\prime}$-Dimethylformamide (DMF), dimethyl sulfoxide (DMSO), chloroform $\left(\mathrm{CHCl}_{3}\right)$, diethyl ether, methanol $(\mathrm{MeOH})$, tetrahydrofuran (THF), ethanol (EtOH), dichloromethane (DCM), n-hexane, npentanol, and acetone were purchased from MERCK. 4Nitrophthalonitrile, 2-hydroxymethyl-1,4-benzodioxan, 1,8diazabicyclo[5.4.0] undec-7-ene (DBU), potassium carbonate $\left(\mathrm{K}_{2} \mathrm{CO}_{3}\right)$, zinc(II) acetate, cobalt(II) acetate, nickel(II) acetate, copper(II) acetate were purchased from Aldrich. All chemicals were of reagent grade. All solvents were dried and stored over molecular sieves. The progress of the reactions was monitored by thin layer chromatography (TLC). Melting points of the substances were determined using an Electrothermal Gallenkamp device. The IR spectra were recorded using a Perkin Elmer spectrophotometer with ATR sampling accessory. UV-Vis spectra were recorded on a Agilent $8453 \mathrm{UV} / \mathrm{Vis}$ spectrophotometer. Elemental analyses were carried out by a LECO CHNS 932 instrument. A Varian Unity Inova $500 \mathrm{MHz}$ spectrophotometer was used for ${ }^{1} \mathrm{H}$ NMR and ${ }^{13} \mathrm{C}$ NMR spectra. Mass spectra of the synthesized substances were acquired by using a Bruker Microflex LT MALDI-TOF MS. GC-MS spectrum was obtained on an Agilent Technologies 6890N GC-System-5973 IMSD.

\subsection{Synthesis of Compounds}

2.2.1. 4-((2,3-Dihydrobenzo[b][1,4]dioxin-2-yl)methoxy)phthalonitrile (1). 2-Hydroxymethyl-1,4-benzodioxan (0.52 g, 2.89 $\mathrm{mmol}$ ) was dissolved in DMF $(30 \mathrm{ml})$ under nitrogen and 4-nitrophthalonitrile $(0.5 \mathrm{~g}, 2.89 \mathrm{mmol})$ was added. After stirring for $20 \mathrm{~min}$ at room temperature, finely ground anhydrous $\mathrm{K}_{2} \mathrm{CO}_{3}(1.96 \mathrm{~g}, 14.45 \mathrm{mmol})$ was added to this mixture in portions over $2 \mathrm{~h}$ with efficient stirring. The reaction mixture was stirred under a nitrogen atmosphere at $50^{\circ} \mathrm{C}$ for a total of $24 \mathrm{~h}$. The reaction mixture was cooled to room temperature and was then poured into $200 \mathrm{ml}$ ice-water, and the precipitate that formed was filtered off, washed with water, n-hexane, and diethyl ether, and then dried. The creamy crude product was recrystallized from $\mathrm{MeOH}$. Finally the pure powder was dried in a vacuum. This compound was soluble in $\mathrm{MeOH}$, EtOH, acetone, $\mathrm{DCM}$, and $\mathrm{CHCI}_{3}$. Yield: 0.76 g (90\%). Mp: $145-146^{\circ}$ C. Anal. Calc. for $\mathrm{C}_{17} \mathrm{H}_{12} \mathrm{~N}_{2} \mathrm{O}_{3}: \mathrm{C}$, 69.86; H, 4.14; N, 9.58. Found: C, 69.55; H, 4.02; N, 9.30\%.
IR (ATR, cm ${ }^{-1}$ ): 3048 (Ar-CH), 2935-2889 (Aliphatic-CH, $\mathrm{CH}_{2}$ ), $2228(\mathrm{C} \equiv \mathrm{N}), 1604-1493(\mathrm{C}=\mathrm{C}), 1275-1253$ (C-O-C), 1091, 848, 760. ${ }^{1} \mathrm{H}$ NMR (Acetone- $\left.\mathrm{d}_{6}\right),(\delta: \mathrm{ppm}): 7.88-7.86$, 7.60-7.59 (d, 2H, Ar-H), 7.43-7.41 (dd, 1H, Ar-H), 6.75-6.71 (m, 4H, Ar-H), 4.56-4.52 (s, 1H, CH), 4.42-4.09 (m, 4H, $\left.\mathrm{CH}_{2}\right) .{ }^{13} \mathrm{C} \mathrm{NMR}\left(\mathrm{CDCl}_{3}\right),(\delta: \mathrm{ppm}): 161.35,142.88,142.32$, $135.37,122.21,122.02,119.79,119.46,117.66,117.48,115.49(\mathrm{C} \equiv \mathrm{N})$, $115.08(\mathrm{C} \equiv \mathrm{N}), 108.25,70.90,67.30,64.64$. MS (GC-MS) $m / z$, Calc.: 292.08, Found: $292[\mathrm{M}]^{+}$.

2.2.2. General Synthesis Procedure for Phthalocyanine Derivatives (2-6). The mixture of phthalonitrile compound (1) $(0.2$ g. $0.69 \mathrm{mmol})$, n-pentanol $(4 \mathrm{~mL}), 1,8$-diazabicyclo[4.5.0] undec-7-ene (DBU) (5 drops), no metal salt for compound (2), and equivalent amounts of anhydrous $\mathrm{Zn}\left(\mathrm{CH}_{3} \mathrm{COO}\right)_{2}$ for compound (3), $\mathrm{Co}\left(\mathrm{CH}_{3} \mathrm{COO}\right)_{2}$ for compound (4), $\mathrm{Ni}\left(\mathrm{CH}_{3} \mathrm{COO}\right)_{2}$ for compound (5), and $\mathrm{Cu}\left(\mathrm{CH}_{3} \mathrm{COO}\right)_{2}$ for compound (6) were heated to $160^{\circ} \mathrm{C}$ and stirred for $24 \mathrm{~h}$ at this temperature under $\mathrm{N}_{2}$ atmosphere. Then, after cooling to room temperature, the reaction mixture was precipitated by the addition of $n$-hexane and filtered off. After washing with hot $\mathrm{MeOH}$ and hot $\mathrm{EtOH}$, the product was purified with column chromatography by using silica gel and $\mathrm{THF} / \mathrm{CHCI}_{3}$ solvent system. The all phthalocyanines (2-6) were soluble in THF, $\mathrm{CHCI}_{3}, \mathrm{DMF}$ and DMSO.

(1) 2(3),9(10),16(17),23(24)-Tetrakis-\{(2,3-dihydrobenzo[b][1, 4]dioxin-2-yl)methoxy\} Phthalocyanine (2). Solvent system for column chromatography was THF : $\mathrm{CHCI}_{3}(100: 3)$. Yield: $65 \mathrm{mg}$ (32\%), Mp: $>200^{\circ} \mathrm{C}$, Anal. calc. for $\mathrm{C}_{68} \mathrm{H}_{50} \mathrm{~N}_{8} \mathrm{O}_{12}$ : C, 69.24; H, 4.30; N, 9.57; Found: C, 69.01; H, 4.05; N, 9.43\%. IR (ATR, $\mathrm{cm}^{-1}$ ): 3289 (single bond NH), 3046 (Ar$\mathrm{CH}), 2929-2871$ (Aliphatic- $\mathrm{CH}, \mathrm{CH}_{2}$ ), 1610-1491 (C=C), 1264-1235 (C-O-C), 1095, 837, 742. ${ }^{1} \mathrm{H}-\mathrm{NMR}\left(\mathrm{CDCI}_{3}\right),(\delta$ : ppm): 7.67-7.58 (bm, 6H, Ar-H), 7.40-7.15 (bm, 6H, Ar$\mathrm{H})$, 6.98-6.82 (bm, 16H, Ar-H), 4.95 (bs, 4H, Aliphatic$\mathrm{CH}), 4.60-4.20\left(\mathrm{bm}, 16 \mathrm{H}\right.$, Aliphatic- $\left.\mathrm{CH}_{2}\right)$. UV-vis (THF, $1 \times$ $\left.10^{-5} \mathrm{M}\right): \lambda_{\max } / \mathrm{nm}(\log \varepsilon): 701$ (4.99), 664 (5.01), 639 (4.82), 607 (4.68), 332 (5.07). MS (MALDI-TOF), ( $m / z)$ : Calc.: 1171.17, Found: $1171.31[\mathrm{M}]^{+}$.

(2) 2(3),9(10),16(17),23(24)-Tetrakis-\{(2,3-dihydrobenzo[b][1, 4]dioxin-2-yl)methoxy\} Phthalocyaninato Zinc(II) (3). Solvent system for column chromatography was THF : $\mathrm{CHCI}_{3}$ (100:3). Yield: $96 \mathrm{mg}(45 \%), \mathrm{Mp}:>200^{\circ} \mathrm{C}$, Anal. calc. for $\mathrm{C}_{68} \mathrm{H}_{48} \mathrm{~N}_{8} \mathrm{O}_{12} \mathrm{Zn}$ : C, 66.16; H, 3.92; N, 9.08; Found: C, 65.97; $\mathrm{H}, 3.55$; N, 8.90\%. IR (ATR, $\mathrm{cm}^{-1}$ ): 3045 (Ar-CH), 2923-2876 (Aliphatic-CH, $\left.\mathrm{CH}_{2}\right), 1606-1489(\mathrm{C}=\mathrm{C}), 1265-1232$ (C-OC), 1091, 843, 742. ${ }^{1} \mathrm{H}-\mathrm{NMR}\left(\mathrm{CDCI}_{3}\right),(\delta: \mathrm{ppm}): 7.74-7.63$ (bm, 6H, Ar-H), 7.40-7.15 (bm, 6H, Ar-H), 6.98-6.44 (bm, $16 \mathrm{H}$, Ar-H), 4.94 (bs, $4 \mathrm{H}$, Aliphatic- $\mathrm{CH}$ ), 4.54-4.17 (bm, 16H, Aliphatic- $\left.\mathrm{CH}_{2}\right)$. UV-vis $\left(\mathrm{THF}, 1 \times 10^{-5} \mathrm{M}\right): \lambda_{\max } / \mathrm{nm}(\log \varepsilon)$ : 675 (5.00), 609 (4.31), 351 (4.68). MS (MALDI-TOF), $(\mathrm{m} / z)$ : Calc.: 1234.54 , Found: $1234.51[\mathrm{M}]^{+}$.

(3) 2(3),9(10),16(17),23(24)-Tetrakis- $\{(2,3-$ dihydrobenzo[b][1, 4]dioxin-2-yl)methoxy\} Phthalocyaninato Cobalt(II) (4). Solvent system for column chromatography was THF : $\mathrm{CHCI}_{3}$ (100:2). Yield: $85 \mathrm{mg}(40 \%), \mathrm{Mp}:>200^{\circ} \mathrm{C}$, Anal. calc. for 
$\mathrm{C}_{68} \mathrm{H}_{48} \mathrm{CoN}_{8} \mathrm{O}_{12}$ : C, 66.50; H, 3.94; N, 9.12; Found: C, 66.05; $\mathrm{H}, 3.55 ; \mathrm{N}, 8.85 \%$. IR (ATR, $\mathrm{cm}^{-1}$ ): 3064 (Ar-CH), 2954-2870 (Aliphatic-CH, $\mathrm{CH}_{2}$ ), 1609-1492 (C=C), 1265-1232 (C-O-C), 1093, 838, 743. UV-vis (THF, $\left.1 \times 10^{-5} \mathrm{M}\right): \lambda_{\max } / \mathrm{nm}(\log \varepsilon)$ : 663 (5.01), 603 (4.54), 329 (5.08). MS (MALDI-TOF), $(\mathrm{m} / z)$ : Calc.: 1227.27, Found: $1227.15[\mathrm{M}]^{+}$.

(4) 2(3),9(10),16(17),23(24)-Tetrakis- $\{(2,3-$ dihydrobenzo[b][1, 4]dioxin-2-yl)methoxy\} Phthalocyaninato Nickel(II) (5). Solvent system for column chromatography was THF : $\mathrm{CHCI}_{3}$ (100:2.5). Yield: $74 \mathrm{mg}(35 \%), \mathrm{Mp}:>200^{\circ} \mathrm{C}$, Anal. calc. for $\mathrm{C}_{68} \mathrm{H}_{48} \mathrm{~N}_{8} \mathrm{NiO}_{12}$ : C, 66.52; H, 3.94; N, 9.13; Found: C, 66.10; $\mathrm{H}, 3.58 ; \mathrm{N}, 8.85 \%$. IR (ATR, $\mathrm{cm}^{-1}$ ): 3044 (Ar-CH), 2927-2871 (Aliphatic-CH, $\mathrm{CH}_{2}$ ), 1608-1491 (C=C), 1264-1237 (C-OC), 1092, 840, 742. ${ }^{1} \mathrm{H}-\mathrm{NMR}\left(\mathrm{CDCI}_{3}\right),(\delta: \mathrm{ppm}): 7.74-7.66$ (bm, 6H, Ar-H), 7.39-7.19 (bm, 6H, Ar-H), 6.98-6.44 (bm, $16 \mathrm{H}, \mathrm{Ar}-\mathrm{H}), 4.95$ (bs, $4 \mathrm{H}$, Aliphatic- $\mathrm{CH}), 4.57-4.21$ (bm, $16 \mathrm{H}$, Aliphatic- $\left.\mathrm{CH}_{2}\right)$. UV-vis $\left(\mathrm{THF}, 1 \times 10^{-5} \mathrm{M}\right): \lambda_{\max } / \mathrm{nm}(\log \varepsilon)$ : 662 (5.10), 612 (4.67), 327 (5.08). MS (MALDI-TOF), $(\mathrm{m} / z)$ : Calc.: 1227.85 , Found: $1227.79[\mathrm{M}]^{+}$.

(5) 2(3),9(10),16(17),23(24)-Tetrakis- $\{(2,3-$ dihydrobenzo[b][1, 4]dioxin-2-yl)methoxy\} Phthalocyaninato Copper(II) (6). Solvent system for column chromatography was THF : $\mathrm{CHCI}_{3}$ (100 : 2.5). Yield: $77 \mathrm{mg}(37 \%)$, Mp: $>200^{\circ} \mathrm{C}$, Anal. calc. for $\mathrm{C}_{68} \mathrm{H}_{48} \mathrm{CuN}_{8} \mathrm{O}_{12}$ : C, 66.26; H, 3.92; N, 9.09; Found: C, 65.90; $\mathrm{H}, 3.56 ; \mathrm{N}, 8.87 \%$. IR (ATR, $\mathrm{cm}^{-1}$ ): 3044 (Ar-CH), 2929-2870 (Aliphatic-CH, $\mathrm{CH}_{2}$ ), 1606-1491 (C=C), 1264-1235 (C-O-C), 1091, 841, 743. UV-vis $\left(\mathrm{THF}, 1 \times 10^{-5} \mathrm{M}\right): \lambda_{\max } / \mathrm{nm}(\log \varepsilon): 675$ (5.01), 611 (4.57), 332 (4.82). MS (MALDI-TOF), $(\mathrm{m} / z)$ : Calc.: 1232.70, Found: $1232.34[\mathrm{M}]^{+}$.

2.3. Fabrication and Characterization of SBDs. The p-type $\mathrm{Si}$ wafers with (100) orientation and resistivity in the $8-10 \Omega \mathrm{cm}$ range were used as substrate. After cleaning the $\mathrm{Si}$ wafers using standard RCA cleaning procedure, Al metal was thermally evaporated under $4 \times 10^{-5}$ mbar pressure onto the $\mathrm{Si}$ wafers and followed by a heat treatment at $500^{\circ} \mathrm{C}$ for $3 \mathrm{~min}$ in $\mathrm{N}_{2}$ atmosphere in order to form the Ohmic contacts. After the removing of native oxide layer on the polished surface of the $\mathrm{Si}$ wafers by $\mathrm{HF} / \mathrm{H}_{2} \mathrm{O}(1: 8)$ solution, thin films of the Pc compounds were formed onto the polished surface of $\mathrm{Si}$ substrate by spin coating technique. The thickness of the films was determined by ellipsometric technique. After the spin coating of the interface layer, $1 \mathrm{~mm}$ in diameter and $2000 \AA$ thick Ag Schottky contacts were deposited on the the Pc layer by thermal evaporation technique. In this way, $\mathrm{Ag} / \mathrm{Pc}$ film/p-Si Schottky barrier diodes were fabricated. Currentvoltage $(I-V)$ characteristics of the devices were measured under vacuum $\left(<10^{-3}\right.$ mbar) using an electrometer (Keithley, Model 617).

\section{Results and Discussion}

3.1. Synthesis and Characterization of Compounds. The general synthetic pathway for the synthesis of 4-((2,3-dihydrobenzo[b] $[1,4]$ dioxin-2-yl)methoxy)phthalonitrile (1) and its metal-free (2), zinc(II) (3), cobalt(II) (4), nickel(II) (5), and copper(II) (6) phthalocyanine complexes was given in Scheme 1. Initial compound $\mathbf{1}$ was synthesized by the nucleophilic aromatic substitution reaction of compound 2hydroxymethyl-1,4-benzodioxan with 4-nitrophthalonitrile, in $\mathrm{DMF}$ at $50^{\circ} \mathrm{C}$ for $24 \mathrm{~h}$. New phthalocyanines (2-6) were synthesized using corresponding anhydrous metal salts and/or without metal salt in $3 \mathrm{~mL}$-pentanol for $24 \mathrm{~h}$ at $160^{\circ} \mathrm{C}$ under $\mathrm{N}_{2}$ atmosphere in the presence of DBU. Structures of synthesized compounds were verified by elemental analysis, UV-vis, FT-IR, ${ }^{1} \mathrm{H}$ NMR, ${ }^{13} \mathrm{C} \mathrm{NMR}$, and mass spectroscopy techniques. According to the IR spectrum of 1, a new vibration that appeared at $2228 \mathrm{~cm}^{-1}$ proved the formation of $\mathbf{1}$. The FT-IR spectrum of $\mathbf{1}$ showed aromatic bond $-\mathrm{CH}$ peaks at around $3013-3048 \mathrm{~cm}^{-1}$ and aromatic $-\mathrm{C}=\mathrm{C}$ peaks at around $1604-1592 \mathrm{~cm}^{-1}$. The stretching peaks at $2935-2880 \mathrm{~cm}^{-1}$ confirmed the presence of $-\mathrm{CH}$ and $-\mathrm{CH}_{2}$ groups. ${ }^{1} \mathrm{H}$ NMR spectrum of $\mathbf{1}$ (Figure S1) exhibited aromatic protons, integrating for a total of 7 protons, at $7.88-7.86,7.60-7.59,7.43-7.41$, and 6.75-6.71 ppm. In addition, $\mathrm{CH}$ and $\mathrm{CH}_{2}$ protons of 1 were observed at 4.56-4.52 and 4.42-4.09 ppm which integrated for 5 protons. ${ }^{13} \mathrm{C}$ NMR of 1 (Figure S2) is another evidence for proposed structure; the new bands observed at 115.49 and 115.08 ppm could be defined as carbons of nitrile groups. The molecular ion peak for 1 was observed at $292 \mathrm{~m} / z$ in its GC-MS spectrum which verified the formation of this phthalonitrile.

FT-IR spectra of the phthalocyanine compounds are very similar to each other. The proposed target structures of all new phthalocyanines were affirmed in the FT-IR spectra by the disappearance of the $-\mathrm{C} \equiv \mathrm{N}$ vibration at $2228 \mathrm{~cm}^{-1}$ for phthalonitrile (1). For metal-free phthalocyanine (2), inner core $-\mathrm{NH}$ vibration was observed at $3289 \mathrm{~cm}^{-1}$, and this peak was the essential difference between the IR spectral data of metallophthalocyanines and metal-free ones. In the FT-IR spectra of phthalocyanines (2-6), stretching vibrations of aromatic $\mathrm{CH}$ groups around $3064-3044 \mathrm{~cm}^{-1}$, aliphatic- $\mathrm{CH}$, $\mathrm{CH}_{2}$ groups around $2954-2870 \mathrm{~cm}^{-1}$, and aromatic $-\mathrm{C}=\mathrm{C}$ groups around $1610-1489 \mathrm{~cm}^{-1}$ appeared at expected frequencies. In the ${ }^{1} \mathrm{H}$ NMR spectra of $\mathbf{2 , 3}$, and 5 phthalocyanines (Figures S3, S4, and S5), the bands belonging to the phthalocyanine and substitute 2-hydroxymethyl-1,4-benzodioxan aromatic protons were observed between 7.67 and $6.82 \mathrm{ppm}$ for compound 2, between 7.74 and $6.44 \mathrm{ppm}$ for compound 3, and between 7.74 and 6.44 ppm for compound 5 as broad multiplet peaks. In addition, the aliphatic- $\mathrm{CH}$ protons for 2 , 3 , and 5 were assigned at around 4.95, 4.94, and $4.95 \mathrm{ppm}$, respectively, as broad single peaks. The aliphatic $\mathrm{CH}_{2}$ protons for 2, 3, and 5 were also assigned at around 4.60-4.20, 4.54-4.17, and 4.57-4.21 ppm, respectively, as broad multiplet peaks. For 2 , the typical shielding of inner core protons could not be observed due to the strong aggregation between Pc molecules [18]. The ${ }^{1} \mathrm{H}$ NMR spectrum of compounds 4 and 6 could not be determined because of the presence of paramagnetic copper and cobalt ions [19]. The MALDI-TOF mass spectra of the phthalocyanines (2-6) show the presence of characteristic peaks at $m / z=1171.31[\mathrm{M}]^{+}$for $2,1234.51$ $[\mathrm{M}]^{+}$for 3, $1227.15[\mathrm{M}]^{+}$for 4, $1227.79[\mathrm{M}]^{+}$for 5, and 1232.34 $[\mathrm{M}]^{+}$for 6 confirming the proposed structures (Figure 1). 
<smiles>N#Cc1ccc([N+](=O)[O-])cc1C#N</smiles><smiles>N#Cc1ccc(OCC2COc3ccccc3O2)cc1C#N</smiles>

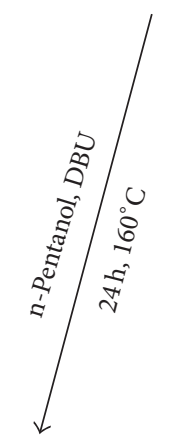

(1)

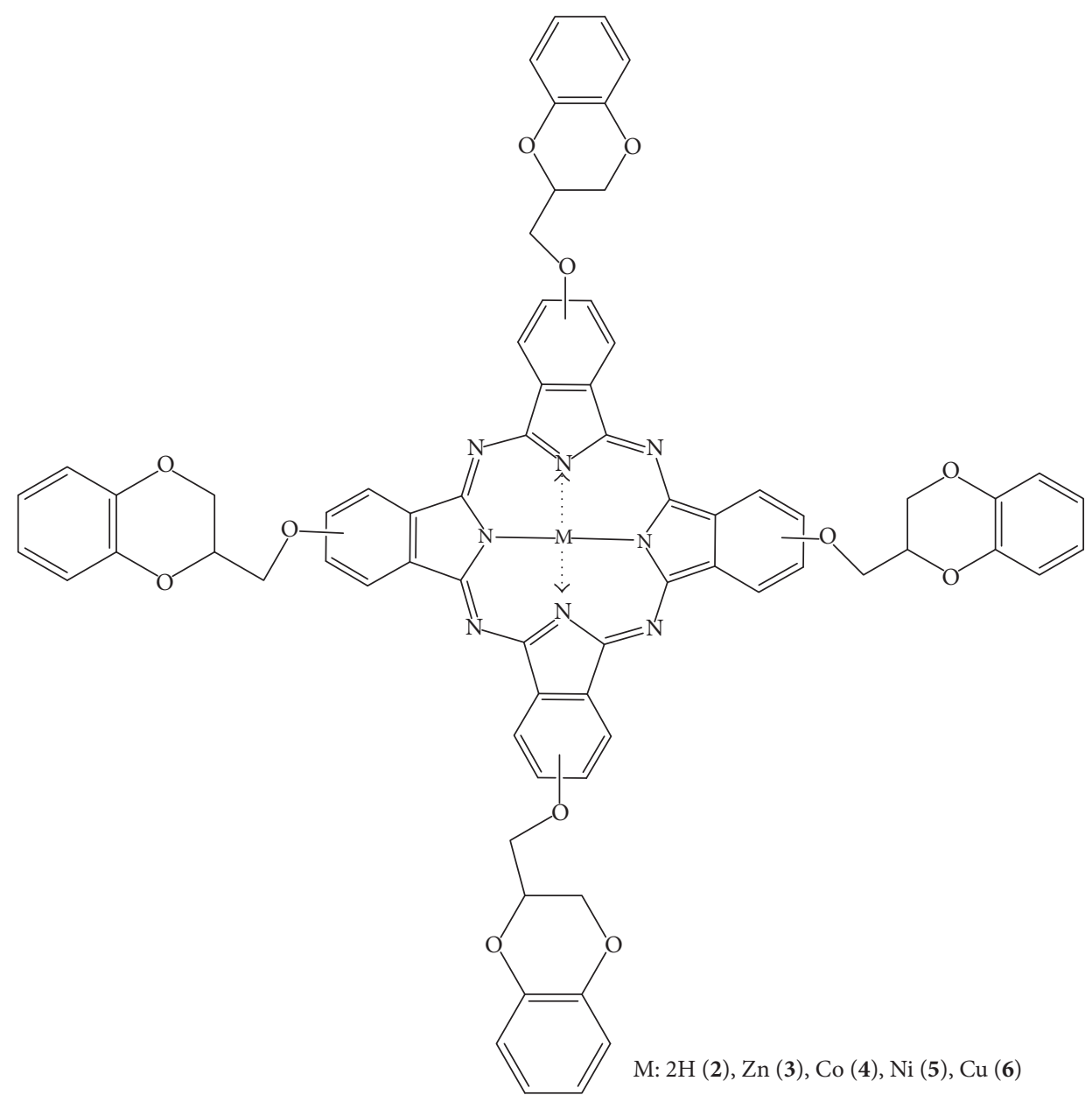

Scheme 1: Schematic representation of synthesized compounds (1-6).

UV-Vis spectroscopy is thought to be the basic method to verify the formation of phthalocyanines. The phthalocyanine compounds show two main electronic transitions named as Q band (600-700 $\mathrm{nm}$ in the visible region), assigned to the $\pi-\pi^{*}$ transition from the highest occupied molecular orbital (HOMO) to the lowest unoccupied molecular orbital (LUMO) of the Pc ring, and B band (300-350 $\mathrm{nm}$ in the UV region), resulting from the deeper $\pi-\pi^{*}$ transitions [20-22]. The UV spectra of the metallophthalocyanines (3-6) display intense Q band at $675 \mathrm{~nm}$ for 3, $663 \mathrm{~nm}$ for $4,671 \mathrm{~nm}$ for $\mathbf{5}$, 

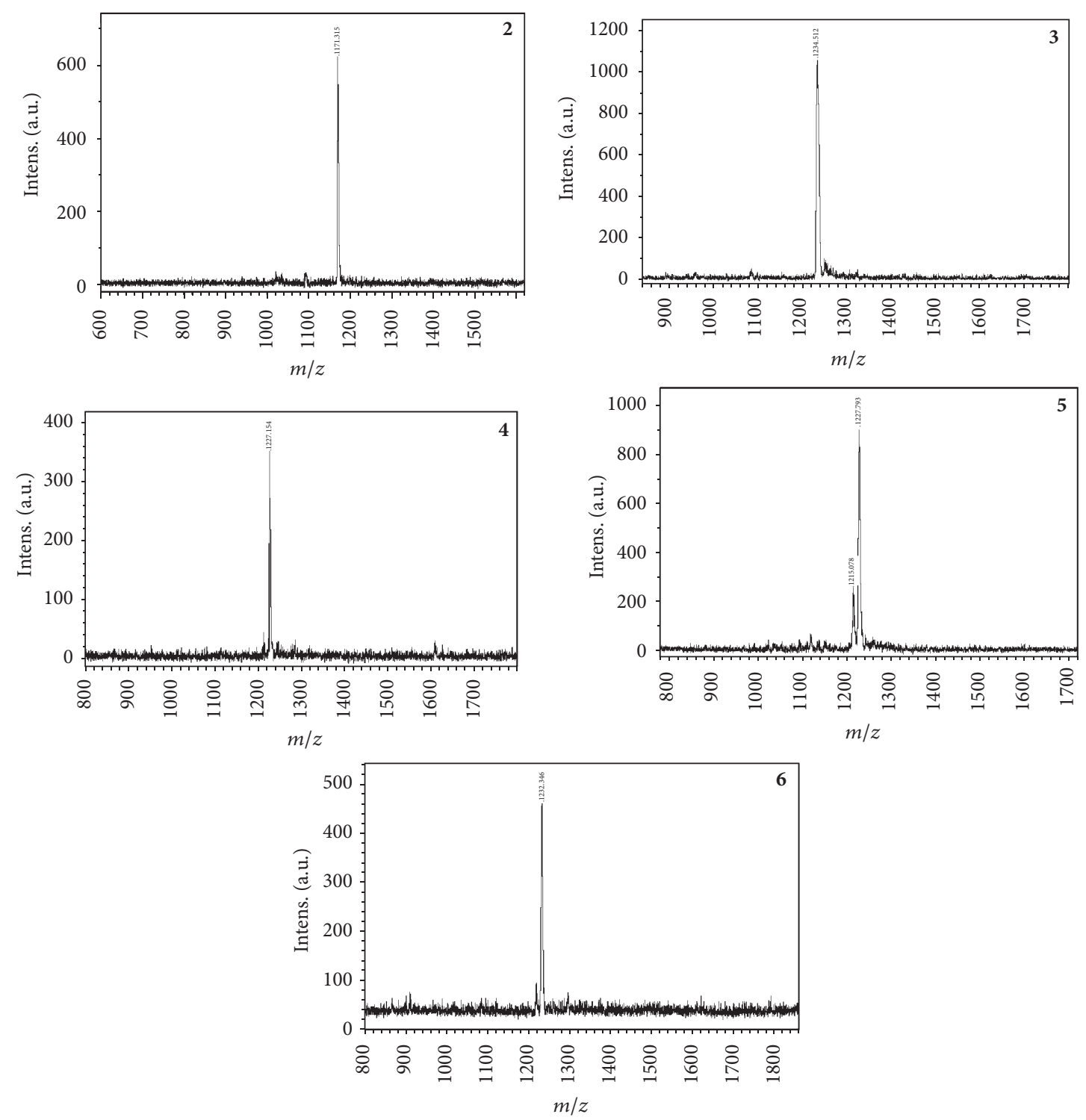

FIGURE 1: The MALDI-TOF MS spectra of the phthalocyanines (2-6).

and $675 \mathrm{~nm}$ for 6 in THF. The shoulders of phthalocyanines 3-6 were observed at 609, 603, 617, and $611 \mathrm{~nm}$, respectively. For the $\mathrm{Q}$ band of phthalocyanines, the longer wavelength absorptions are owing to the monomeric species and shorter wavelengths (shoulders) are due to the aggregated species [2]. The B bands were observed at $351 \mathrm{~nm}$ for 3, $329 \mathrm{~nm}$ for 4, $327 \mathrm{~nm}$ for 5, and $341 \mathrm{~nm}$ for $\mathbf{6}$. For the metal-free phthalocyanine (2), a split Q band was observed at 701 and $664 \mathrm{~nm}$, while B band was observed at $332 \mathrm{~nm}$ (Figure 2).

3.2. Characterization of SBDs. A device without Pc interface layer was also fabricated in order to verify the efficacy of the insertion of Pc layer on the charge transfer characteristic of the devices. For comparison, the room temperature current density $(J)$ voltage characteristics of the devices are presented in Figure 3. As is clear from Figure 3, all the devices exhibit rectification behavior with different rectification ratio between 7 for $\mathrm{Ag} / \mathrm{p}$-Si and 310 for $\mathrm{Ag} / 2 / \mathrm{P}-\mathrm{Si}$ structure at \pm 5 . This results prove the good rectification performance for the Pc layer inserted devices. Leakage current is an important factor influencing the performance of an SBD. It was found that the value of the leakage current density for the Pc layer inserted devices varies between 2.29 $\times 10^{-7} \mathrm{~A} / \mathrm{cm}^{2}$ and $6.56 \times 10^{-7} \mathrm{~A} / \mathrm{cm}^{2}$, while the observed leakage current density was $1.38 \times 10^{-4} \mathrm{~A} / \mathrm{cm}^{2}$ for $\mathrm{Ag} / \mathrm{p}-\mathrm{Si}$ structure. It should be mentioned here that the observed level of leakage current density is significantly low when compared with the reported values with similar structure such as Au/PDI/p-Si [23] and Al/DNA/p-Si [24] Schottky devices. This findings clearly show that the main performance parameters of a SBD such as rectification ratio and leakage current can be improved by modifying $\mathrm{p}$-type silicon surface with 2(3),9(10),16(17),23(24)-tetrakis- $\{(2,3$ dihydrobenzo[b][1,4]dioxin-2-yl)methoxy\}phthalocyanines. 


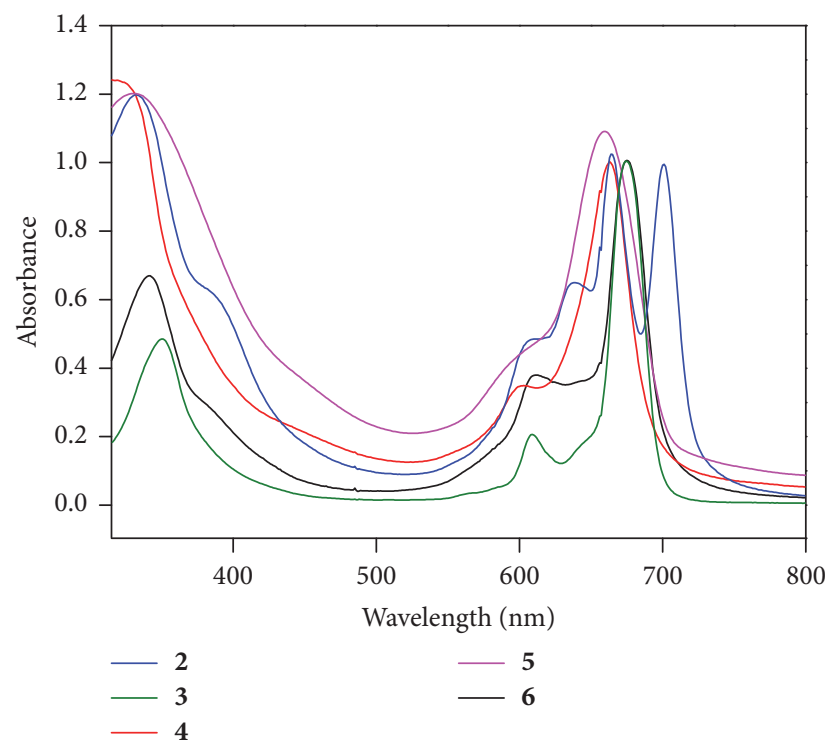

FIGURE 2: UV-Vis spectra of phthalocyanines (2-6).

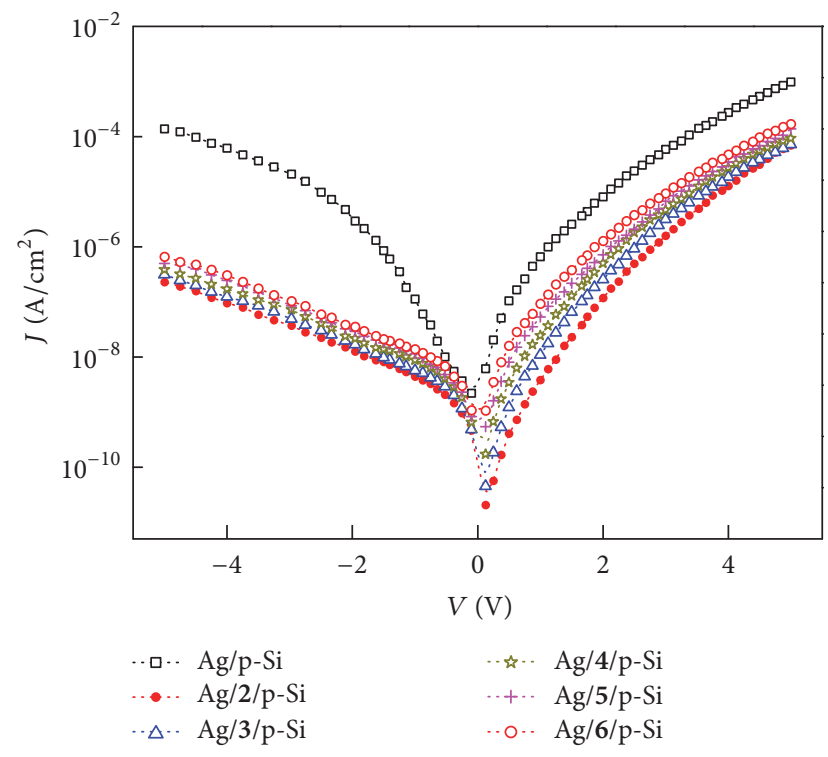

FIgURE 3: Room temperature $J-V$ characteristics of the devices.

Various models, such as Fowler-Nordheim tunneling, Poole-Frenkel emission, and Ohmic and space charge limited (SCL) current, have widely been used to understand the nature of the charge transport through an organic thin film [25-27]. To investigate the dc conduction mechanism in fabricated devices, the obtained $J-V$ data were replotted on double logarithmic scale for forward and reverse bias conditions in Figure 4.

It will be clear from the analysis of the data presented in Figures 4(a) and 4(b) that there are two regions with different slopes in double logarithmic $J-V$ plots for both forward and reverse bias conditions, which is consistent with earlier reports on Metal/Phthalocyanine/Metal (MIM) structures
$[28,29]$. A relatively small slope in $J-V$ curves at low voltage regions is clear for both directions. Special attention must be given to interpreting the presented data in Figure 4, because different conduction mechanism can give rise to this type of $J-V$ characteristics. A close analysis of the slopes of the curves shown in Figure 4 indicates that the slopes of the curves vary between 0.92 and 1.16 for reverse bias conditions, which is indicative of the Ohmic conduction in this voltage region. On the other hand, it was observed that the slopes of the $J-V$ curves for forward bias vary between 2.15 and 2.68, which cannot be considered in the framework of Ohmic conduction. Therefore, in order to identify the conduction mechanism taking place in $\mathrm{Ag} / \mathrm{Pc} / \mathrm{p}-\mathrm{Si}$ structures, the $J-V$ curves of the fabricated devices were analyzed separately for forward and reverse bias directions. As mentioned before, the reverse bias $J-V$ characteristic of the devices at lower voltage range can be explained by the Ohmic behavior of the device. However, a power law dependence in the form of $J \alpha V^{s}$ with $s>2$ reveals the presence of space charge limited conductivity (SCLC) controlled by exponentially distributed trapping levels. This type of $J-V$ characteristic has been observed in some other Pc films such as copper phthalocyanine thin film [30]. It should be mentioned here that the reverse bias voltage at which the exponent $s$ deviates from unity is nearly the same for all Pc modified devices. In order to investigate whether our experimental data can be explained using Poole-Frenkel emission, we have plotted, in Figure $5, \ln (J / V)$ versus $V^{1 / 2}$ curves for all samples.

In the case of Poole-Frenkel emission, the relationship between the current density and the applied voltage can be expressed as given in [15]

$$
J=A \frac{V}{d} \exp \left(\frac{q \varphi_{\mathrm{PF}}-\beta_{\mathrm{PF}} \sqrt{V / d}}{a k T}\right),
$$

where $A$ is a fitting parameter, $d$ is the thickness of the film, $q \varphi_{\mathrm{PF}}$ is the required energy for an electron to escape from the 


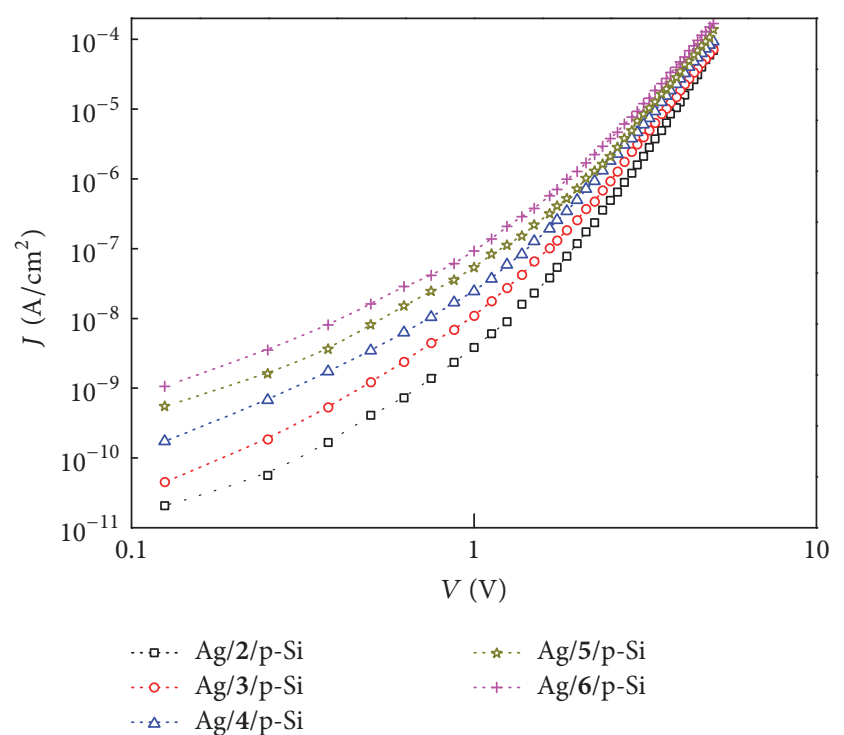

(a)

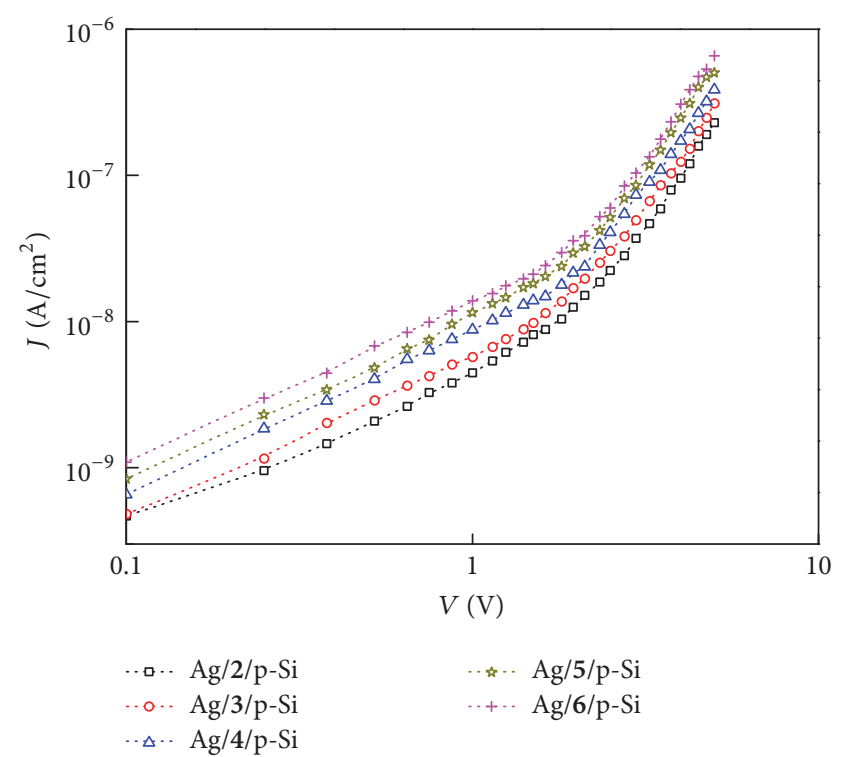

(b)

Figure 4: $J-V$ plots for forward (a) and reverse bias (b) conditions.

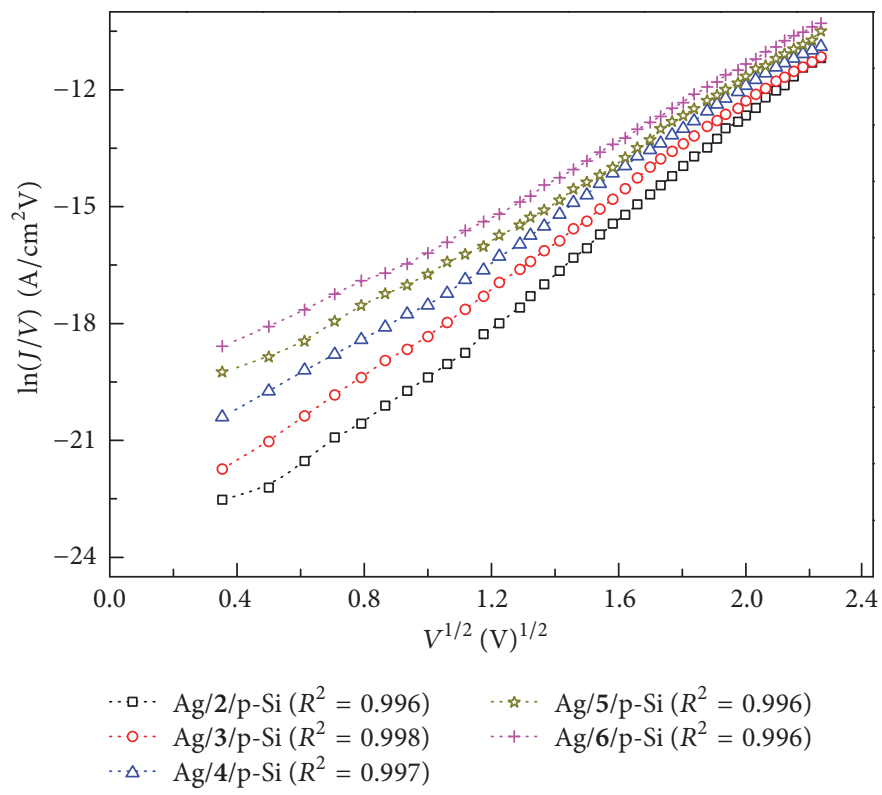

FIGURE 5: Poole-Frenkel plots for the device investigated under forward bias condition.

trap, $a$ is the slope parameter, and $\beta_{\mathrm{PF}} \sqrt{V}$ is barrier lowering. According to (1), the plot of $\ln (J / V)$ versus $\sqrt{V}$ should be linear if the charge transport takes place through PooleFrenkel emission. Good correlation coefficients $\left(R^{2}\right)$ obtained from $\ln (J / V)$ versus $\sqrt{V}$ plots reveal that the mechanism responsible for conduction in $\mathrm{Ag} / \mathrm{Pc} / \mathrm{p}-\mathrm{Si}$ structures under forward bias conditions can be described by the PooleFrenkel emission.

\section{Conclusion}

In this work, we have defined the synthesis and characterization of peripherally tetrasubstituted metal-free, zinc, cobalt, nickel, and copper phthalocyanine derivatives. These new five compounds were characterized by various techniques. In order to get more quantitative information about charge transport mechanism and the usability of these compounds to modify the main SBD parameters such as rectification ratio and the leakage current, SBDs with the structure of $\mathrm{Ag} / \mathrm{Pc} / \mathrm{p}$ $\mathrm{Si}$ were fabricated and characterized. Our experimental results showed that charge transport in these compounds take place via different mechanism in reverse and forward bias conditions. Results from this preliminary analysis indicated that the compounds can be considered, among other candidates, as a potential passivation layer for the new SBD diodes with high rectification ratio and low leakage current. 


\section{Conflicts of Interest}

The authors declare that they have no conflicts of interest.

\section{Acknowledgments}

This study was supported by the Research Fund of Yildiz Technical University (Project no. 2016-01-02-DOP01).

\section{Supplementary Materials}

Figure S1. 1H-NMR spectrum of compound 1. Figure S2. 13C-NMR spectrum of compound 1. Figure S3. 1H-NMR spectrum of compound 2. Figure S4. $1 \mathrm{H}$-NMR spectrum of compound 3. Figure S5. 1H-NMR spectrum of compound 5. (Supplementary Materials)

\section{References}

[1] N. B. McKeown, Phthalocyanine Materials: Synthesis, Structure and Function, Cambridge University Press, Cambridge, UK, 1998.

[2] C. C. Leznoff, A. B. P. Lever, P. Stuzhin, O. Khelevina, and B. Berezin, Phthalocyanines: Properties and Applications, $\mathrm{VCH}$ Publishers, New York, NY, USA, 1996.

[3] M. Bouvet, P. Gaudillat, and J.-M. Suisse, "Phthalocyaninebased hybrid materials for chemosensing," Journal of Porphyrins and Phthalocyanines, vol. 17, no. 10, pp. 913-919, 2013.

[4] C. G. Claessens, U. Hahn, and T. Torres, "Phthalocyanines: From outstanding electronic properties to emerging applications," The Chemical Record, vol. 8, no. 2, pp. 75-97, 2008.

[5] M. Kraus, S. Richler, A. Opitz et al., "High-mobility copperphthalocyanine field-effect transistors with tetratetracontane passivation layer and organic metal contacts," Journal of Applied Physics, vol. 107, no. 9, Article ID 094503, 2010.

[6] T. Basova, A. Hassan, M. Durmuş, A. G. Gürek, and V. Ahsen, "Liquid crystalline metal phthalocyanines: Structural organization on the substrate surface," Coordination Chemistry Reviews, vol. 310, pp. 131-153, 2016.

[7] D. S. Weiss and M. Abkowitz, "Advances in organic photoconductor technology," Chemical Reviews, vol. 110, no. 1, pp. 479526, 2010.

[8] R. Ao, L. Kümmerl, and D. Haarer, "Present limits of data storage using dye molecules in solid matrices," Advanced Materials, vol. 7, no. 5, pp. 495-499, 1995.

[9] M.-E. Ragoussi, M. Ince, and T. Torres, "Recent advances in phthalocyanine-based sensitizers for dye-sensitized solar cells," European Journal of Organic Chemistry, no. 29, pp. 6475-6489, 2013.

[10] Y. Zhang, X. Cai, Y. Bian, and J. Jiang, "Organic semiconductors of phthalocyanine compounds for field effect transistors (FETs)," in Functional Phthalocyanine Molecular Materials, J. Jiang, Ed., vol. 135 of Structure and Bonding, pp. 275-321, Springer, Berlin, Germany, 2010.

[11] D. Dini, M. J. F. Calvete, and M. Hanack, "Nonlinear optical materials for the smart filtering of optical radiation," Chemical Reviews, vol. 116, no. 22, pp. 13043-13233, 2016.

[12] A. Altindal, Ş. Abdurrahmanoǧlu, M. Bulut, and Ö. Bekaroğlu, "Charge transport mechanism in bis(double-decker lutetium(III) phthalocyanine) (Lu2Pc4) thin film," Synthetic Metals, vol. 150, no. 2, pp. 181-187, 2005.
[13] T. S. Shafai and T. D. Anthopoulos, "Junction properties of nickel phthalocyanine thin film devices utilising indium injecting electrodes," Thin Solid Films, vol. 398-399, pp. 361-367, 2001.

[14] N. N. Halder, P. Biswas, S. Kundu, and P. Banerji, "Au/p-Si Schottky junction solar cell: Effect of barrier height modification by InP quantum dots," Solar Energy Materials \& Solar Cells, vol. 132, pp. 230-236, 2015.

[15] E. Rhoderick and R. Williams, Metal-Semiconductor Contacts, Clarendon, Oxford, UK, 2nd edition, 1988.

[16] S. Yadav and S. Ghosh, "Amorphous strontium titanate film as gate dielectric for higher performance and low voltage operation of transparent and flexible organic field effect transistor," ACS Applied Materials \& Interfaces, vol. 8, no. 16, pp. 1043610442, 2016.

[17] J. Tardy, M. Erouel, A. L. Deman et al., "Organic thin film transistors with $\mathrm{HfO} 2$ high-k gate dielectric grown by anodic oxidation or deposited by sol-gel," Microelectronics Reliability, vol. 47, no. 2-3, pp. 372-377, 2007.

[18] Ü. Demirbaş, M. Pişkin, B. Barut, R. Bayrak, M. Durmuş, and H. Kantekin, "Metal-free, zinc(II) and lead(II) phthalocyanines functioning with 3-(2H-benzo[d][1,2,3]triazol-2-yl)4-hydroxyphenethyl methacrylate groups: Synthesis and investigation of photophysical and photochemical properties," Synthetic Metals, vol. 220, pp. 276-285, 2016.

[19] Ü. Demirbaş, D. Akyüz, B. Barut, R. Bayrak, A. Koca, and H. Kantekin, "Electrochemical and spectroelectrochemical properties of thiadiazole substituted metallo-phthalocyanines," Spectrochimica Acta Part A: Molecular and Biomolecular Spectroscopy, vol. 153, pp. 71-78, 2016.

[20] G. Gümrükçü, M. Ü. Özgür, A. Altindal, A. R. Özkaya, B. Salih, and Ö. Bekaroğlu, "Synthesis and electrochemical, electrical and gas sensing properties of novel mononuclear metal-free, $\mathrm{Zn}$ (II), Ni(II), Co(II), Cu(II), Lu(III) and double-decker Lu(III) phthalocyanines substituted with 2-(2H-1,2,3-benzotriazol- 2yl)-4-(1,1,3,3-tetramethylbutyl) phenoxy," Synthetic Metals, vol. 161, no. 1-2, pp. 112-123, 2011.

[21] Ö. Koyun, S. Gördük, B. Keskin, A. Çetinkaya, A. Koca, and U. Avciata, "Microwave-assisted synthesis, electrochemistry and spectroelectrochemistry of phthalocyanines bearing tetra terminal-alkynyl functionalities and click approach," Polyhedron, vol. 113, pp. 35-49, 2016.

[22] G. K. Karaoğlan, G. Gümrükçü, S. Gördük, N. Can, and A. Gül, "Novel homoleptic, dimeric zinc(II) phthalocyanines as gate dielectric for OFET device," Synthetic Metals, vol. 230, pp. 7-11, 2017.

[23] Ö. F. Yüksel, N. Tuğluoğlu, H. Şafak, and M. Kuş, “The modification of Schottky barrier height of Au/p-Si Schottky devices by perylene-diimide," Journal of Applied Physics, vol. 113, no. 4, Article ID 044507, 2013.

[24] H. M. J. Al-Ta'ii, Y. M. Amin, and V. Periasamy, "Calculation of the electronic parameters of an Al/DNA/p-Si schottky barrier diode influenced by alpha radiation," Sensors, vol. 15, no. 3, pp. 4810-4822, 2015.

[25] B. Keskin, A. Altindal, U. Avciata, and A. Gül, "A.C. and D.C. Conduction processes in octakis[(4-tert-butylbenzylthio)porphyrazinato] $\mathrm{Cu}(\mathrm{II})$ thin films with gold electrodes," Bulletin of Materials Science, vol. 37, no. 3, pp. 461-468, 2014.

[26] B. Keskin, S. Arda Öztürkcan, and A. Altindal, "Ultrasoundassisted rapid one-pot synthesis, characterization and electrical properties of a $\beta$-aminoketone with a ferrocenyl moiety," Polyhedron, vol. 69, pp. 135-140, 2014. 
[27] F.-C. Chiu, "A review on conduction mechanisms in dielectric films," Advances in Materials Science and Engineering, vol. 2014, Article ID 578168, 18 pages, 2014.

[28] T. G. Abdel Malik and R. M. Abdel-Latif, "Ohmic and spacecharge limited conduction in cobalt phthalocyanine thin films," Thin Solid Films, vol. 305, no. 1-2, pp. 336-340, 1997.

[29] A. C. Varghese and C. S. Menon, "Electrical properties of nickel phthalocyanine thin films using gold and lead electrodes," Journal of Materials Science: Materials in Electronics, vol. 17, no. 2, pp. 149-153, 2006.

[30] A. K. Hassan and R. D. Gould, "The electrical properties of copper phthalocyanine thin films using indium electrodes," Journal of Physics D: Applied Physics, vol. 22, no. 8, pp. 1162-1168, 1989. 

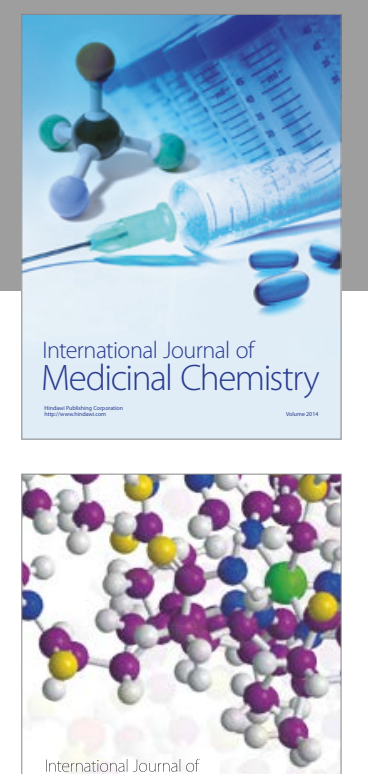

Carbohydrate Chemistry

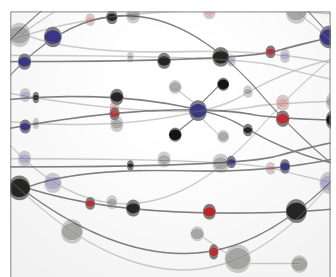

The Scientific World Journal
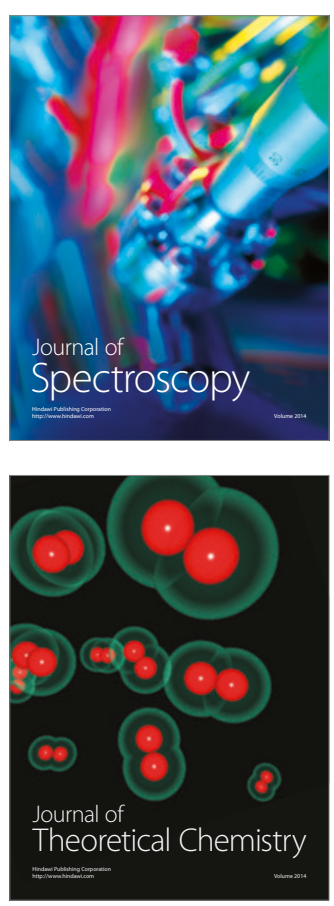
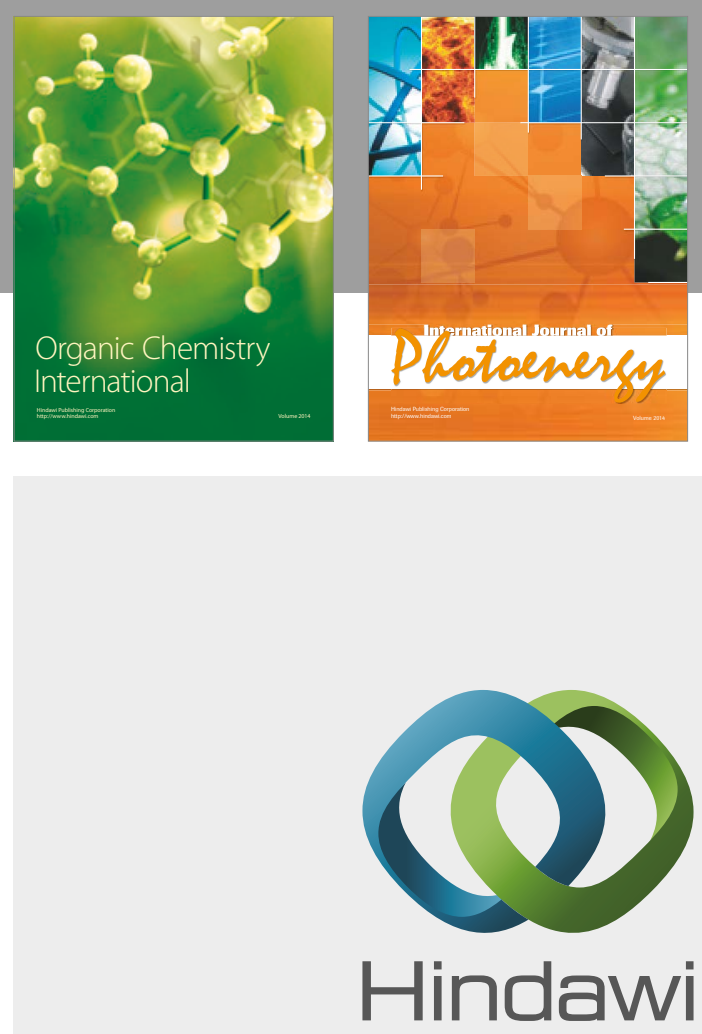

Submit your manuscripts at

https://www.hindawi.com

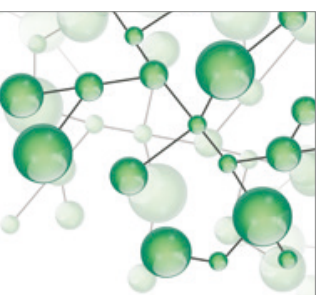

International Journal of

Inorganic Chemistry

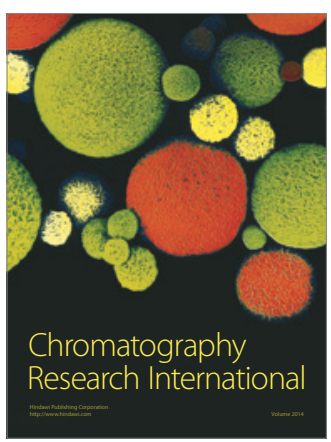

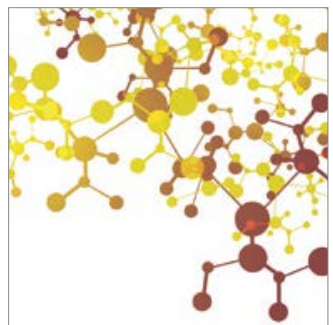

Applied Chemistry
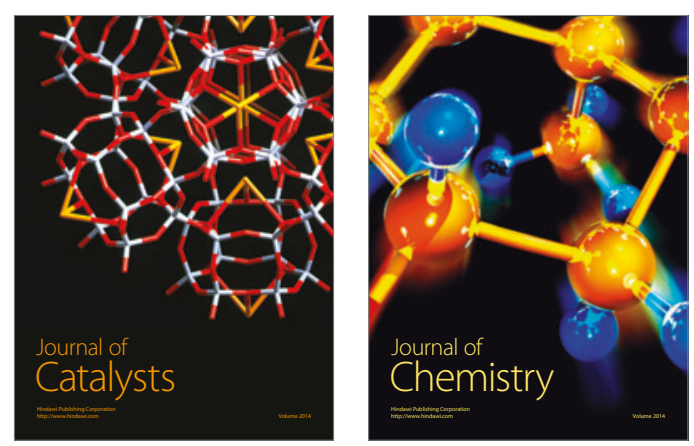
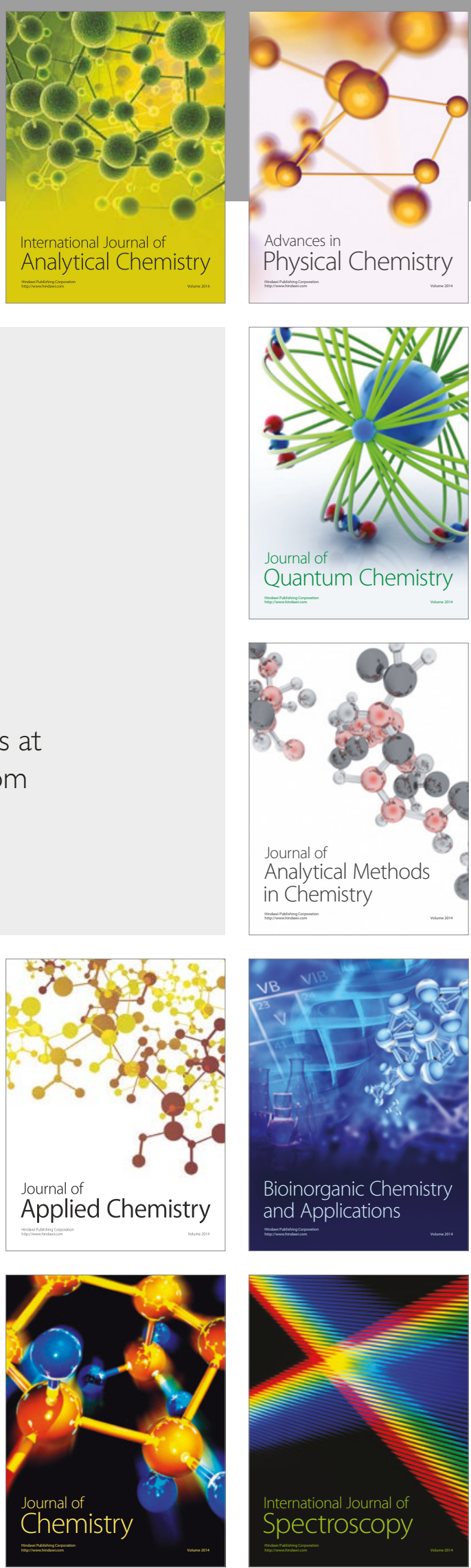